\title{
A comparative acoustic analysis of species of Vitreorana (Anura: Centrolenidae) from the Brazilian Atlantic Forest and Cerrado, with a description of the call of $V$. baliomma and insights into the taxonomic status of Cerrado populations
}

\footnotetext{
Davi Lee Bang, ${ }^{1,2,3}$ Barnagleison Silva Lisboa, ${ }^{4,5}$ Bernardo Franco da Veiga Teixeira, ${ }^{2}$ Ariovaldo Antonio Giaretta, ${ }^{2}$ and Thiago Ribeiro de Carvalho ${ }^{6}$

${ }^{1}$ Laboratório de Zoologia de Vertebrados, Faculdade de Filosofia, Ciências e Letras de Ribeirão Preto, Universidade de São Paulo (USP). Av. Bandeirantes, 3900, 14040-901, Ribeirão Preto, SP, Brazil. E-mail: davileebang@yahoo.com.br; davileebang@usp.br.

${ }^{2}$ Laboratório de Taxonomia, Sistemática e Evolução de Anuros Neotropicais, Instituto de Ciências Naturais do Pontal, Universidade Federal de Uberlândia (UFU). Rua 20, 1600, 38304-402, Ituiutaba, MG, Brazil.

${ }^{3}$ Programa de Pós-Graduação em Biologia Comparada, Departamento de Biologia/FFCLRP, Universidade de São Paulo (USP). Av. Bandeirantes, 3900, 14040-901, Ribeirão Preto, SP, Brazil.

${ }^{4}$ Setor de Zoologia, Museu de História Natural, Universidade Federal de Alagoas (UFAL). Praça Afrânio Jorge s/n, 57010020, Maceió, AL, Brazil.

${ }_{5}^{5}$ Programa de Pós-Graduação em Biologia Animal, Departamento de Zoologia, Centro de Biociências, Universidade Federal de Pernambuco (UFPE). Av. Professor Moraes Rego, 1235, 50670-901, Recife, PE, Brazil.

${ }^{6}$ Laboratório de Herpetologia, Departamento de Zoologia e Centro de Aquicultura, Universidade Estadual Paulista Júlio de Mesquita Filho (UNESP). Rio Claro, SP, Brazil.
}

\begin{abstract}
A comparative acoustic analysis of species of Vitreorana (Anura: Centrolenidae) from the Brazilian Atlantic Forest and Cerrado, with a description of the call of $V$. baliomma and insights into the taxonomic status of Cerrado populations. Advertisement calls are the primary signaling strategy of mating in most anurans. Examining major patterns within and across frog taxa may help to delimit species and understand acoustic communication systems. Herein, the vocalization of Vitreorana baliomma is described and new acoustic descriptions are provided for $V$. franciscana and $V$. eurygnatha. Calls of syntopic/sympatric or allopatric populations were compared. The vocalization of $V$. baliomma is composed of two call types-A and B, with Call A being the advertisement call. The vocalization of $V$. franciscana is composed of only one call type (Call A), emitted isolated or in series. The vocalization of V. eurygnatha has two types of calls; Call A is similar among Cerrado populations, whereas an Atlantic Forest population has a distinct Call A pattern. The calls of each of these species of the present study is pulsed; however,
\end{abstract}

Received 03 September 2019

Accepted 20 February 2020

Distributed June 2020 
the calls differ in call duration, pulse organization, or pulse duration, and these differences seem to reflect the allopatric or sympatric/syntopic occurrences of populations. The unique call pattern of the Atlantic Forest population of $V$. eurygnatha may represent the advertisement call of the nominal species, and the distinct call of the Cerrado population may indicate cryptic diversity in the species.

Keywords: Advertisement call, character displacement, sympatry, syntopy, vocal repertoire, Vitreorana baliomma, Vitreorana eurygnatha, Vitreorana franciscana.

\begin{abstract}
Resumo
Uma análise acústica comparativa de espécies de Vitreorana (Anura: Centrolenidae) da Mata Atlântica e do Cerrado brasileiros, com a descrição do canto de $V$. baliomma e considerações sobre o status taxonômico de populações do Cerrado. Cantos de anúncio representam a forma primária de sinalização para reprodução na maioria dos anuros. Avaliar os principais padrões dentro e entre táxons de anuros pode auxiliar na delimitação de espécies e no entendimento de sistemas de comunicação acústica. Nesse trabalho, a vocalização de Vitreorana baliomma é descrita e novas descrições acústicas são fornecidas para $V$. franciscana e $V$. eurygnatha. Cantos entre populações em sintopia/simpatria ou alopatria foram comparados. A vocalização de $V$. baliomma é composta de dois tipos de cantos-A e B, e o Canto A considerado como o canto de anúncio. A vocalização de $V$. franciscana é composta por um único tipo de canto (Canto A), que é emitido isoladamente ou em séries. A vocalização de V. eurygnatha possui dois tipos de cantos; o Canto A é similar entre populações do Cerrado, enquanto que uma população da Mata Atlântica possui o Canto A com um padrão distinto. Os cantos de cada espécies do presente trabalho são pulsados; no entanto, os cantos diferem em duração do canto, organização dos pulsos, ou duração dos mesmos, e essas diferenças parecem refletir a condição de alopatria ou simpatria/sintopia entre populações. O padrão único observado para a população da Mata Atlântica de V. eurygnatha provavelmente representa o canto de anúncio da espécie nominal, e o canto distinto da população do Cerrado pode indicar diversidade críptica na espécie.
\end{abstract}

Palavras-chave: canto de anúncio, deslocamento de caráter, repertório vocal, simpatria, sintopia, Vitreorana baliomma, Vitreorana eurygnatha, Vitreorana franciscana.

\section{Introduction}

Advertisement calls are the primary form of communication in most anuran species. These calls are often conspicuous, stereotyped signals produced by reproductively active male frogs (Wells 2007). Female frogs react to specific call traits of conspecific males. Thus, advertisement calls can act as reproductive barriers between species (Blair 1958, 1964), and can have immediate effect on acoustic signal divergence (Boul et al. 2007). Vocalization traits can be used for species delimitations (Köhler et al. 2017), particularly when interspecific call differences emerge among frogs sharing overlapping vocalization sites (i.e., syntopic or sympatric occurrence; Höbel and Gerhardt 2003, Hoskin et al. 2005, Jansen et al. 2016), or among morphologically cryptic species that have different acoustic traits (Angulo and Reichle 2008, Carvalho et al. 2019). Therefore, speciation patterns can be informed by acoustic descriptions that may reveal processes underlying the evolution of mating signals.

Although patterns of advertisement call evolution in centrolenid frogs have been evaluated at a macroevolutionary scale (Escalona et al. 2019), calls of some species of Vitreorana (Guayasamin et al. 2009) have not been described-viz., V. baliomma Pontes, Cara- 
maschi, and Pombal, 2014 and V. parvula (Boulenger, 1895). The calls of about $80 \%$ of centrolenids are either unknown or lack detailed descriptions (Dautel et al. 2011). The lack of acoustic data impedes our understanding of the systematics of Glass Frogs such as Vitreorana (Castroviejo-Fisher et al. 2011), and hinders assessments of intraspecfic variation.

We predict that Brazilian species of Vitreorana have different advertisement calls because vocalizations usually are species specific in anurans, especially in taxa that co-occur (syntopic species) in the Atlantic Forest and Cerrado. Further, we expect that different populations of a same species will share a basic acoustic pattern, apart from variations related to environmental factors (e.g., temperature) and morphological constraints (e.g., body size). Herein, we describe the advertisement call of $V$. baliomma, and provide new call descriptions for $V$. eurygnatha (Lutz, 1925) and V. franciscana Santana, Barros, Pontes, and Feio, 2015 from other regions/biomes. Our analysis enabled us to compare major acoustic patterns combined with morphological traits between species which show allopatric and sympatric / syntopic occurrences.

\section{Materials and Methods}

\section{Sampling}

The following species of Vitreorana were sampled from Brazilian localities, as follow. Vitreorana baliomma: Estação Ecológica de Murici $\left(09^{\circ} 12^{\prime} 32^{\prime \prime}\right.$ S, 3551'37" W, $463 \mathrm{~m}$ a.s.l.; datum WGS84 in all cases) in Murici, state of Alagoas (AL). Vitreorana eurygnatha and $V$. franciscana, which occur syntopically at the following localities: Parque Nacional da Serra da Canastra $\left(20^{\circ} 18^{\prime} 05^{\prime \prime}\right.$ S, 46³1'19" W, 850 m a.s.1.) in Vargem Bonita, state of Minas Gerais (MG); and Córrego Borrachudo (19 $19^{\prime} 40^{\prime \prime} \mathrm{S}$, $46^{\circ} 00^{\prime} 1$ " W, 1123 m a.s.1.) in São Gotardo (MG). Vitreorana eurygnatha: Reserva Biológica Augusto Ruschi (1953'49" S, 40³2'30" W, 838 $m$ a.s.1.) in Santa Teresa, state of Espírito Santo (ES).

Recordings and specimens of Vitreorana franciscana from Vargem Bonita were the same analyzed by Santana et al. (2015). Acoustic data for $V$. uranoscopa (Müller, 1924) were obtained from Haga et al. (2014) and Zaracho (2014). Appendix I contains detailed information on sound recordings, including the voucher specimens. Calls were recorded in the field with digital recorders (M-audio Microtrack ${ }^{\circledR}$ II and Marantz $^{\circledR} \quad$ PMD 660) and unidirectional microphones (Sennheiser ${ }^{\circledR}$ K6/ME67 and K6/ ME66). The recorders were adjusted to sampling rates of $44.1 \mathrm{kHz}$ or $48.0 \mathrm{kHz}$ and bit depth of 16 points. Files were stored as uncompressed wave files. Sound files and specimens were deposited in the following Brazilian collections: Collection of Amphibians of the Universidade Federal de Uberlândia (AAG-UFU), Uberlândia, Minas Gerais state; Museu de Zoologia João Moojen (MZUFV) at Universidade Federal de Viçosa, Viçosa, Minas Gerais state; and Herpetological Collection of the Museu de História Natural (MUFAL) at Universidade Federal de Alagoas, Maceió, Alagoas state.

\section{Species Identification}

Specimens from Murici ( $N=8$ males) were identified as Vitreorana baliomma based on features from the original description (Pontes et al. 2014): snout-vent length $(\mathrm{SVL})=17.8-21.4$ mm $($ mean $=19.4, \mathrm{SD}=1.1)$; vomerine teeth absent; snout truncate in dorsal view and rounded in lateral view; tympanum non-pigmented with outline barely visible and supratympanic fold poorly developed around the upper portion of the tympanum; dorsal skin texture smooth; poorly defined nuptial pad; Finger I longer than Finger II; in life, green dorsum with minute white punctuations; in preservative, dorsum cream with small and star-shaped melanophores distributed uniformly; and hands and feet yellowish with melanophores, when present, restricted to the dorsal portion of Finger IV and Toes IV and V. 
Specimens of Vitreorana eurygnatha from Vargem Bonita ( $N=1$ male), São Gotardo $(N=$ 2) and Santa Teresa $(N=2)$ were identified based on the following traits provided by Santana et al. (2015): SVL = 16.9-20.5 mm $($ mean = 18.5, SD = 1.4); snout truncate in dorsal and lateral views; dorsal skin texture smooth; rounded melanophores distributed uniformly on the dorsum; tympanum non-pigmented; and tubercles in the cloacal region rounded, with similar size, and poorly pigmented.

Specimens of Vitreorana franciscana from São Gotardo ( $N=2$ males) were identified on the basis of Santana et al. (2015): SVL $=21.3-21.5$ $\mathrm{mm}($ mean $=21.4, \mathrm{SD}=0.1)$; snout sub-ovoid in dorsal view; sloping in profile; dorsal skin texture shagreen; melanophores clustered on the dorsum; tympanum white; tubercles enameled, forming two prominences on each side of the cloaca; upper lip ridge of tubercles absent; ridges on the outer surfaces of forearms, shanks, and tarsi discrete; iris tan with black encircling reticulations.

\section{Acoustic Analysis}

The following settings in Raven Pro 1.5 (Center for Conservation Bioacoustics 2014) were used for the acoustic analysis: window type $=$ Hann, window size $=256$ samples, $3 \mathrm{~dB}$ filter bandwidth $=270 \mathrm{~Hz}$ or $248 \mathrm{~Hz}$, window overlap $($ locked $)=90 \%$, hop size $=0.54$ or 0.59 $\mathrm{ms}$, DFT size $=1024$ samples, grid spacing $=$ 46.9 or $43.1 \mathrm{~Hz}$. Sound figures were produced using seewave 1.7.6 (Sueur et al. 2008) and tune $\mathrm{R}$ 1.3.2 (Ligges et al. 2018), packages implemented in R 3.6.1 ( $\mathrm{R}$ Development Core Team 2015), using the following parameters: window type $=$ Hann, FFT overlap $=90 \%$, FFT size $=256$ points. Spectrograms were produced with a relative amplitude color scale of $36 \mathrm{~dB}$ (red = maximum amplitude).

The following acoustic traits were analyzed: call duration (time from onset to offset of vocal emission), number of pulses per call (amplitude modulations within call, both complete and incomplete), pulse rate (quotient of number of pulses by each call duration), pulse duration (time comprised from onset to offset of amplitude modulations within calls), interval between pulses (duration of silent gaps between pulses), interval between calls (measured only when calls were emitted in sequence or when a different type of call was emitted shortly after main call type), and the call dominant frequency (point of greatest energy in advertisement call).

Two types of calls were recognized. Call A, the most frequently emitted signal, is the advertisement call. Call B differs from Call A in temporal structure, such as the envelope, or noticeable differences in duration, pulse number and their temporal organization. We did not use the Call B of $V$. franciscana described by Santana et al. (2015) because we noted that it seems to correspond to Call A of this study, although it was emitted as a calling bout with relatively lower amplitude (Results).

\section{Results}

Calls (both A and B) of all three Vitreorana species analyzed are pulsed. However, they differ in temporal patterns (e.g., call duration, pulse number, and repetition rates; Table 1). Calls are emitted in different patterns as follow: in most cases, (1) a single Call A (i.e., advertisement); (2) a single Call A followed by a sequence of the same call with shorter intervals; (3) a Call B (single or in sequence) shortly after a Call A. Quantitative descriptions of each species calls are presented below.

\section{Vocalization of Vitreorana baliomma}

The vocalization is composed of two different call types (Table $1 ; N=1$ male recorded from Murici, AL): Call A ( $N=13$ calls; Figure 1) usually followed by a Call B $(N=10$ cases; $N=$ 10 calls; Figure 1); however, Call A may also be emitted alone ( $N=3$ cases). Call A has complete amplitude modulations (always with 7 pulses) and increases slightly in amplitude along the 


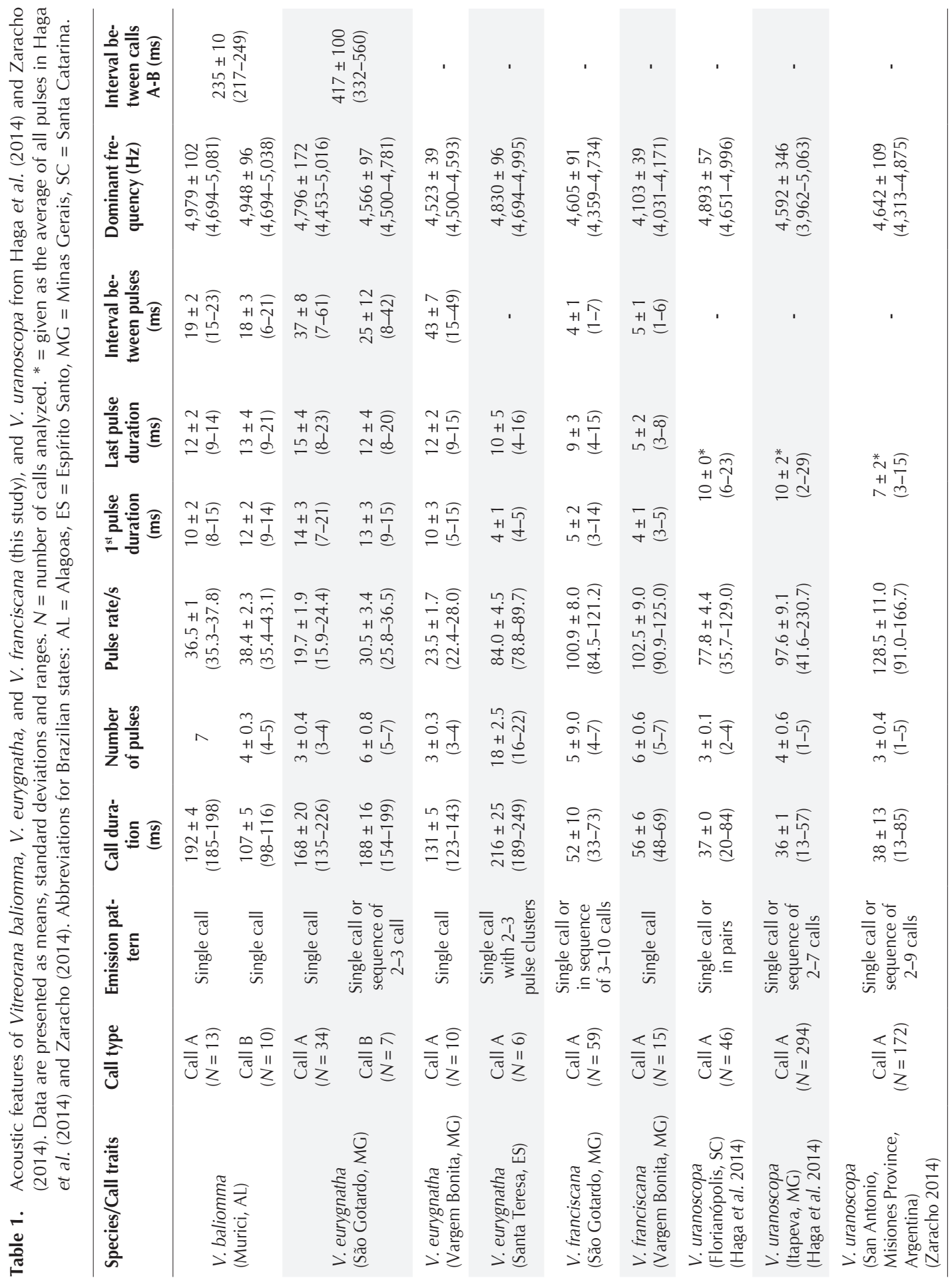




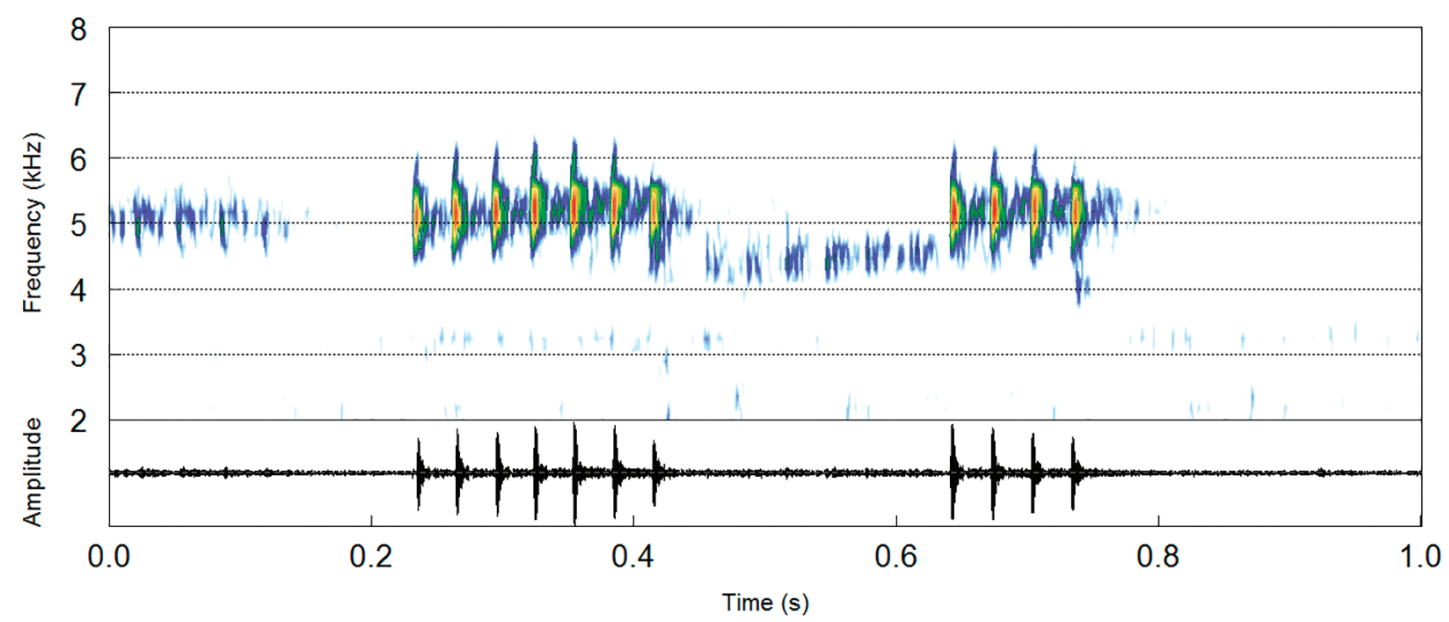

Figure 1. Spectrogram and corresponding oscillogram of the vocalization of Vitreorana baliomma from Murici: Call A followed by a Call B. Sound file = Vitreorana_baliomma_Murici-Alagoas-BSLISBOA-29.IV.13_MZ000032. See further information on recordings in Appendix I.

call. Call A duration varies from 185-198 ms. Pulses are emitted at a rate of 35.3-37.8 pulses/s. The dominant frequency ranges from 4694-5081 Hz. When Call A is followed by a Call B, the interval between them varies from 217-249 ms. Call B also is pulsed, though composed of fewer modulations. Call B duration varies from 98-116 $\mathrm{ms}$ and is formed by 4 or 5 pulses, which are emitted at a similar rate compared to Call A. The dominant frequency ranges from 4694-5038 Hz.

\section{Vocalization of Vitreorana eurygnatha}

The vocalization of the population from São Gotardo is composed of two call types (Table 1; Figures $2 \mathrm{~A} ; N=3$ males). Call A ( $N=34$ calls) is pulsed and has complete amplitude modulations. It has a slight increase in amplitude along the call. Call A duration varies from 135$226 \mathrm{~ms}$ and has 3 or 4 pulses. Pulses are emitted at a rate of 15.8-24.9 pulses/s. In some instances, the first pulse has remarkably lower amplitude. The dominant frequency ranges from 4453-5016 Hz. Call B ( $N=3$ calls; Figure $2 \mathrm{~A})$ was emitted by only one male as a single call ( $N=2$ cases) or in sequences ( $N=2$ cases) of two or three calls.
Call B always is emitted shortly after a Call A and has the same overall pulse structure. However, Call B has different and irregular patterns of amplitude modulation, more pulses (5-7) and lower intensity (Figure 2A). The interval between Calls A and B varies from 332$560 \mathrm{~ms}$. Each Call B has a duration of 154-199 ms. Pulses are emitted at a rate of 25.8-36.5 pulses/s. The dominant frequency ranges from 4500-4781 Hz. When Calls B are emitted in sequences, the interval between them varies from 389-649 $\mathrm{ms}($ mean $=518, \mathrm{SD}=130)$.

Only Call A $(N=1$ male) was recorded in the population of Vitreorana eurygnatha from Vargem Bonita, possibly due to the small sample size. The call (Figure 2B) is mostly consistent with the acoustic description for recordings from São Gotardo; however, slight differences were found in quantitative traits such as call duration, pulse rate, and dominant frequency (Table 1).

Vitreorana eurygnatha from Santa Teresa has a different call from those of the Cerrado populations described above. The vocalization is composed of a single call type, Call A (Figure 2C; Table $1 ; N=2$ males) for comparative purposes. Calls are pulsed with complete or 
incomplete amplitude modulations and formed by two distinct portions. The first has a progressive increase in amplitude until it reaches the second part, in which two or three pulse clusters are formed and separated by brief gaps of silence. The duration of Call A is similar to that of the Cerrado populations, ranging from 189-249 ms, but has a remarkably greater pulse number (16-22). Pulses are emitted at a higher rate (78.8-89.7 pulses/s) compared to Cerrado populations. The dominant frequency is quite similar, ranging from 4694-4995 Hz.

\section{Vocalization of Vitreorana franciscana}

The vocalization of the population of Vitreorana franciscana from São Gotardo is composed of Call A (Figures 3A; Table 1; $N=2$ males; 59 calls), which is pulsed and has complete amplitude modulations. Calls are broadcast in two different ways; the first is a single call, and the second is a sequence of calls with lower amplitude that follow shortly after a first high-amplitude call (Figure 3A). Call A lasts 33-73 $\mathrm{ms}$ and has 4-7 pulses (Figure 3A). Pulses are emitted at a rate of 84.5-121.2 pulses/s. In some cases, last pulses can have longer duration than the others, with or without internal and incomplete amplitude modulation. The dominant frequency ranges from 4359-4734 $\mathrm{Hz}$.

Only one specimen of Vitreorana franciscana was recorded from Vargem Bonita. The calls (Figure 3B; $N=1$ male) resemble the overall structure described for calls from São Gotardo; they have similar values for temporal traits (Table 1), but have a lower dominant frequency (4031-4171 Hz).

\section{Discussion}

The acoustic data for Vitreorana baliomma is informative as additional evidence to the diagnosis of this species from northeastern Brazil; however, owing to the limited sample size, we cannot assess intraspecific variation and patterns of call emission. Additional sampling should be conducted at the type locality of the species in the southern part of Bahia and from intermediate populations between the type locality and Murici, from which we obtained acoustic data (Figure 4), to assess the taxonomic identity of Vitreorana populations across coastal Atlantic forests in northeastern Brazil. Nevertheless, the description of calls of $V$. baliomma enables comprehensive acoustic comparisons with the calls of other Glass Frogs (Escalona et al. 2019).

Our study reveals that species of Vitreorana with calls already described from the Brazilian Atlantic Forest and Cerrado (V. eurygnatha, V. franciscana, and $V$. uranoscopa) diverge quantitatively, especially in cases of syntopy/ sympatry. In comparing the calls of these species, we noted two trends. First, in the case of syntopic species (e.g., V. eurygnatha and $V$. franciscana; Figures 2A, B, 3A, B, and 4), there are pronounced differences in the calls. Second, in the case of allopatric species (e.g., $V$. franciscana and $V$. uranoscopa; Figures 3 and 4), calls are similar. We assume that the presence or absence of selective pressures influence characteristics of acoustic mating signals in sympatric and allopatric populations of these frogs, respectively, and that these pressures are reinforced by reproductive isolation in response to sexual selection (Blair 1964, Hoskin et al. 2005). Therefore, in cases of sympatric occurrence, acoustic niche partitioning (Duellman and Pyles 1983, Höbel and Gerhardt 2003) between species of Vitreorana may have triggered selective pressures to avoid signal overlapping.

Calls of Atlantic Forest and Cerrado populations assigned to Vitreorana eurygnatha differ categorically (call envelope) and quantitatively in some temporal traits. The type locality of $V$. eurygnatha is located in a region of Atlantic Forest (Figure 4), which might be an indication that the calls described in our study from the Atlantic forest of Santa Teresa may belong to the call pattern of the nominal species. This is supported by a previous call description 

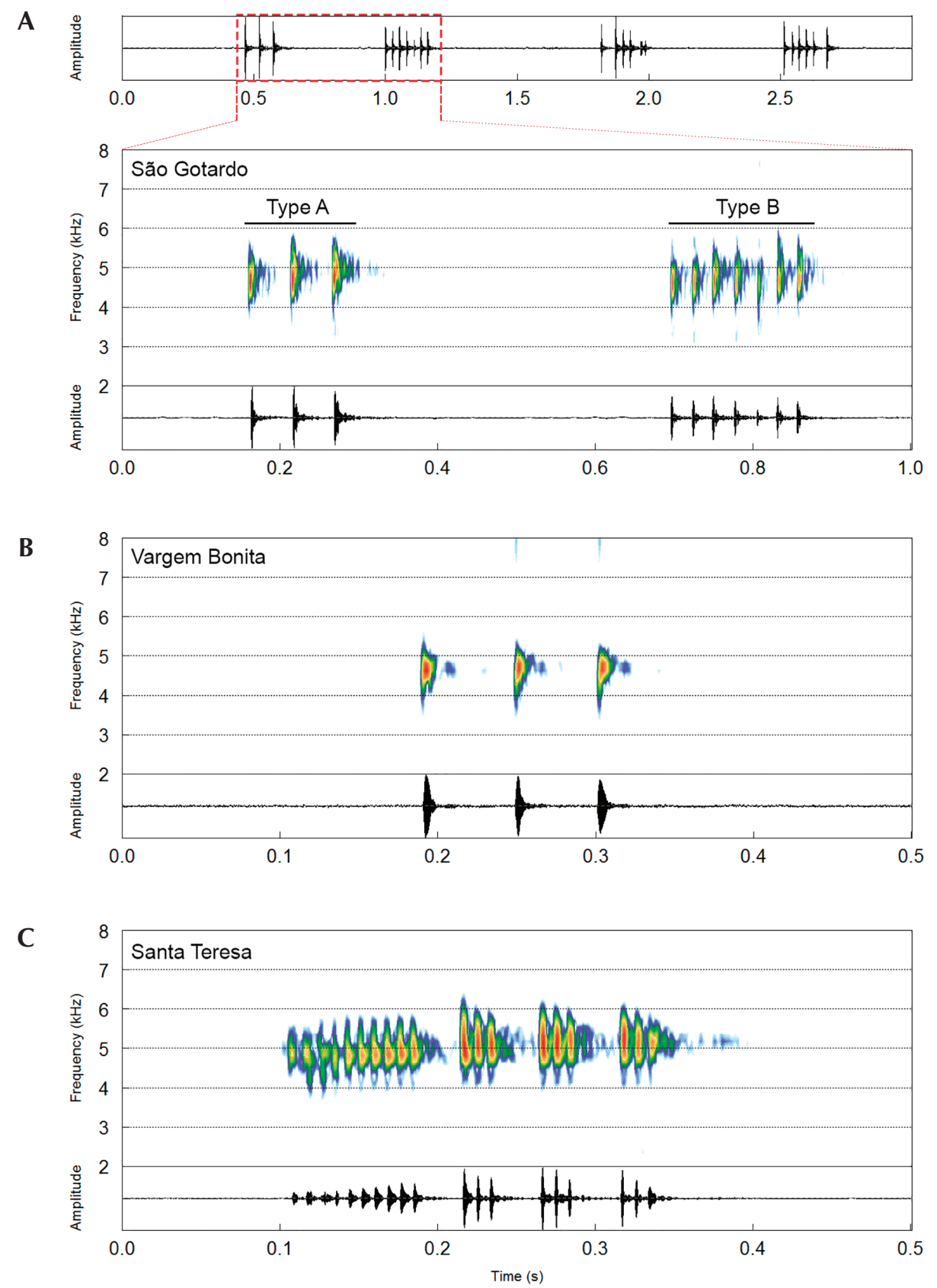

Figure 2. Vocalizations of different populations of Vitreorana eurgynatha. (A): a cut (São Gotardo population) containing a Call A followed by a sequence of three Calls B. Lower panel detailing the section outlined: spectrogram and corresponding oscillogram of a Call A and the first Call B of the sequence (sound file = Vitreor_eurygnathaSGotardoMG3dTRC_AAGmt); $($ B) a Call A from Vargem Bonita (sound file = Vitreor_eurygnathaCanastraMG1aTRC_AAGmt); (C) a Call A from Santa Teresa (sound file = Vitreorana_ eurygnata_SantaTeresa-ES_2_BFVT_AAG_m). See further information on recordings in Appendix I. 

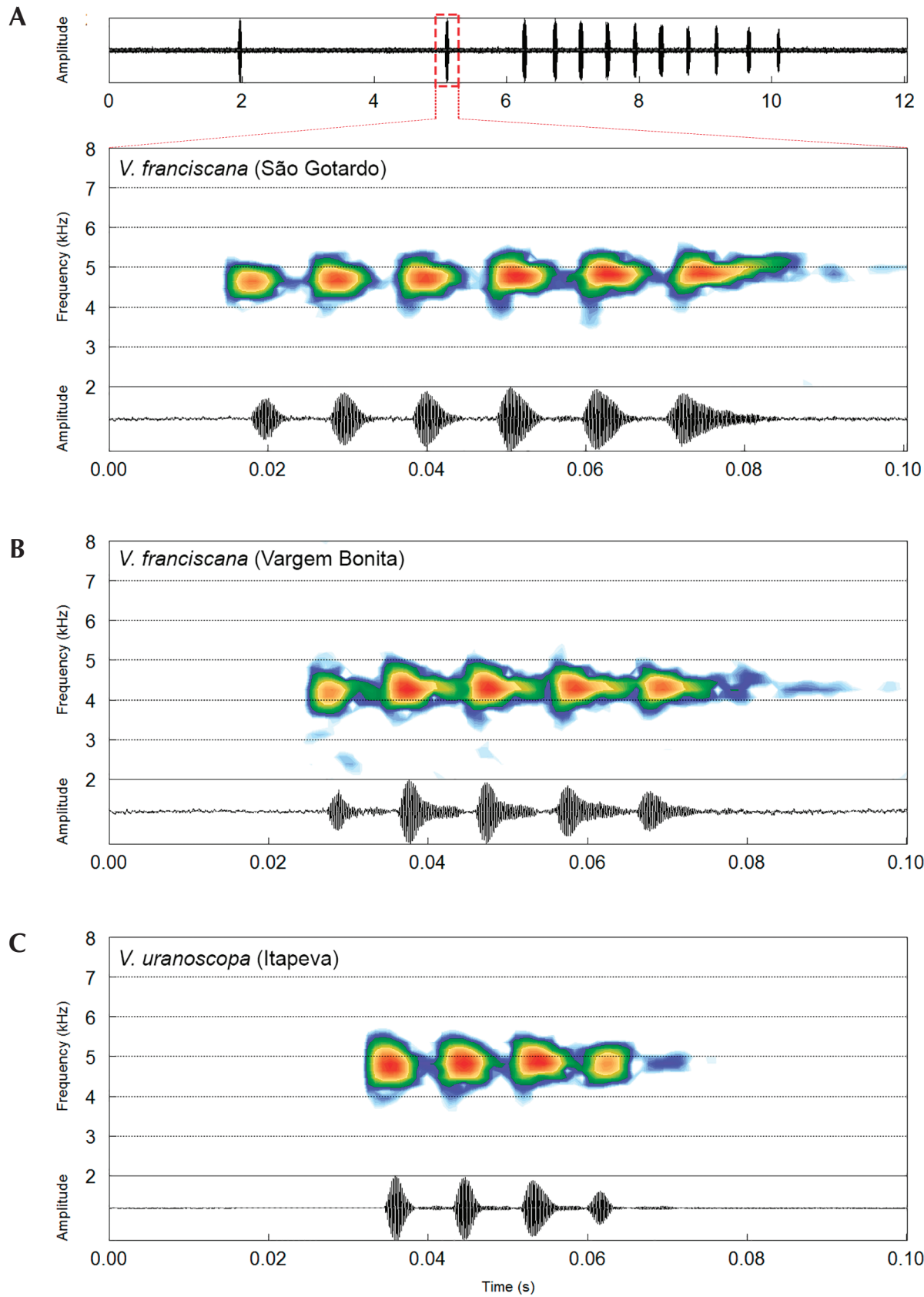

Figure 3. (A) Two Calls A of Vitreorana franciscana (São Gotardo); the second one (highlighted) is followed by a sequence of Call A. Highlighted panel corresponds to the spectrogram and oscillogram of the Call A in detail (sound file $=$ Vitreor_franciscanaSGotardMG1aTRC_AAGmt); (B) a Call A of $V$. franciscana from Vargem Bonita (sound file = Vitreor_franciscanaCanastraMG1cLM_AAGmt); (C) a comparative Call A of $V$. uranoscopa from Itapeva, Minas Gerais, southeastern Brazil (sound file = Vitreor_ uranoscltapevaMG3aAAGm671). See further information on recordings in Appendix I. 


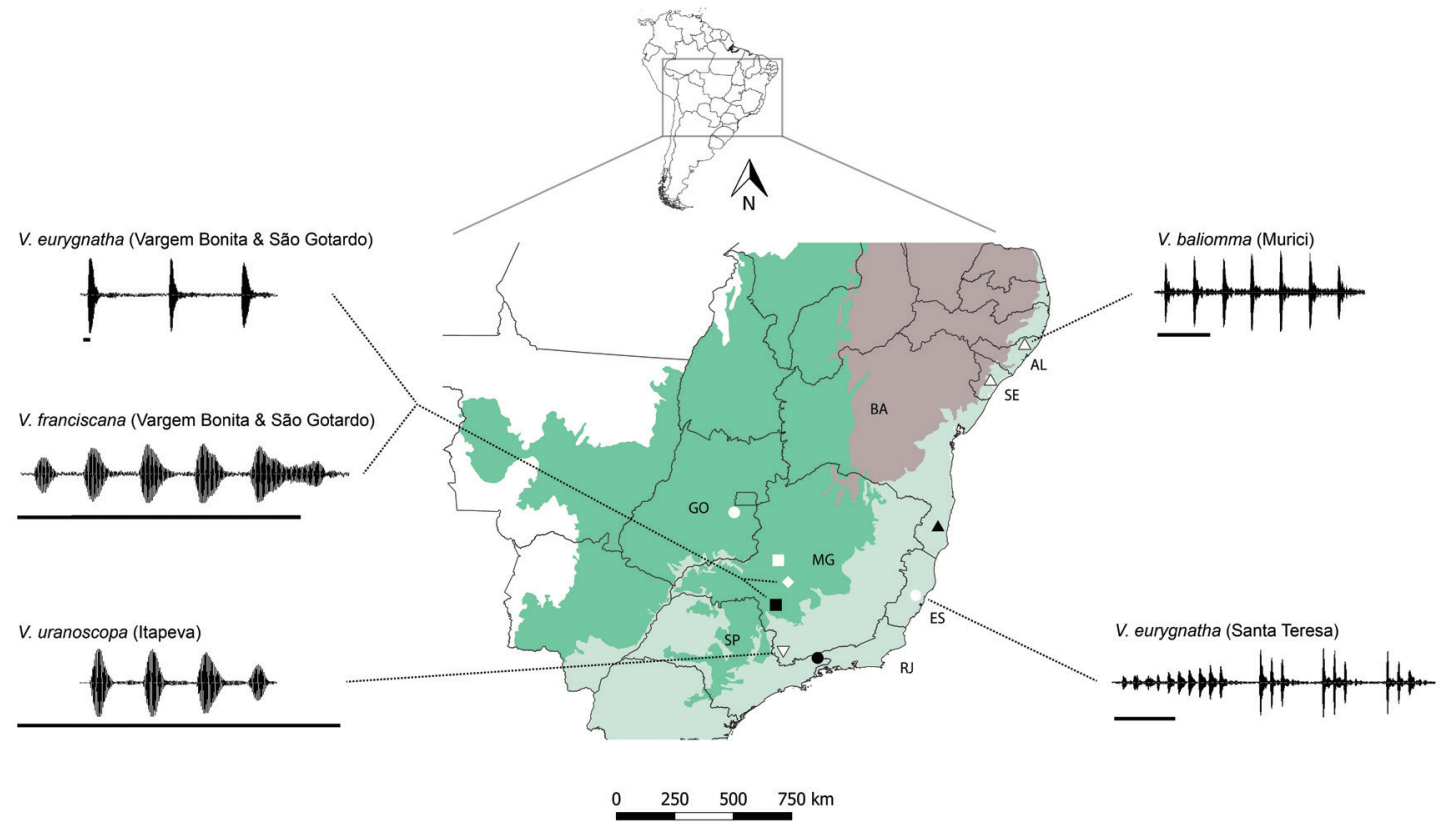

Figure 4. A map of Vitreorana species from Cerrado or Atlantic Forest of Brazil depicting the advertisement call of each species or population from localities sampled in the present study: Vitreorana baliomma in black triangle = Itamaraju, type locality; white triangles = previous northernmost record, Areia Branca (SE), and northernmost record in Murici (AL) of V. baliomma; further occurrence records in Lisboa et al. (2019). Vitreorana eurygnatha in black circle = Serra da Bocaina, type locality; white circles = in the REBIO Augusto Ruschi, municipality of Santa Teresa (ES); and Luziânia (GO) (Cintra et al. 2013). Vitreorana franciscana in black square = PARNA da Serra da Canatra, Vargem Bonita, MG, type locality; white square = Presidente Olegário (MG). Rhomboid symbol represents São Gotardo (MG), a common occurrence point for both $V$. eurygnatha and $V$. franciscana. Inverted triangle = one point of occurrence for $V$. uranoscopa from Haga et al. (2014). Abbreviations for Brazilian states: $\mathrm{AL}=$ Alagoas; $\mathrm{BA}=$ Bahia; $\mathrm{ES}=$ Espírito Santo; $\mathrm{GO}=\mathrm{Goiás;}$ MG = Minas Gerais; RJ = Rio de Janeiro; SE = Sergipe; SP = São Paulo. Scale bars for oscillograms $=0.05$ ms.

of $V$. eurygnatha from Boracéia (Heyer et al. 1990) that agrees with the calls described by us. The striking differences between calls from the Atlantic Forest and the Cerrado emphasize the need of a taxonomic review of populations assigned to $V$. eurygnatha from Cerrado. Moreover, additional Atlantic Forest populations should have their calls evaluated to determine the extent to which acoustic variation across the range of the species coincides with genetic structure within $V$. eurygnatha (see Paz et al. 2018).
Although members of Vitreorana distributed in the Brazilian Atlantic Forest and Cerrado have a similar overall call structure, the calls differ in quantitative traits; thus, they are species specific in some cases, especially between sympatric species. This study highlights the relevance of acoustic data to inform the taxonomic status of members of the genus. This is particularly relevant to the acoustically divergent populations of $V$. eurygnatha, which are assigned to the same species based on their assumed lack of morphological differentiation. Our findings 
suggest that future research should investigate possible mechanisms related to acoustic niche partitioning in sympatric species of Vitreorana. To that end, acoustic divergences between sympatric populations of Vitreorana should be evaluated to determine whether the differences in calls is explained by short-term adjustments in their vocalization (behavioral plasticity) in response to acoustic niche overlap (Höbel and Gerhardt 2003) or, alternately, by fixed geographical variation in call patterns that may match variations in genetic structure (Velásquez et al. 2013) resulting from historical factors such as genetic drift (Irwin et al. 2008), natural selection (Velásquez et al. 2018), or landscape configuration (Paz et al. 2018) in sympatric populations of Vitreorana.

\section{Acknowledgments}

We thank L. B. Martins, L. Magrini, and A. B. Barros for their help at PARNA da Serra da Canastra. We thank R. N. Feio and C. L. de Assis for providing information on MZUFV specimens. We are grateful to the management staff of REBIO de Santa Teresa and PARNA da Serra da Canastra for allowing us to conduct fieldwork and for providing infrastructure. L. M. Borges, J. S. Junior, R. L. S. Cazarotti, and I. B. Guarda provided insightful comments on drafts of this manuscript. Fundação de Amparo à Pesquisa do Estado de São Paulo (FAPESP) currently provides a doctoral fellowship to DLB (process \#2017/27137-7) and a postdoctoral fellowship to TRC (process \#2017/08489-0). Conselho Nacional de Desenvolvimento Científico e Tecnológico $(\mathrm{CNPq})$ provided a Master's fellowship to BSL (process \#132436/2012-4). Coordenação de Aperfeiçoamento de Pessoal de Nível Superior (CAPES) provided a doctoral fellowship to BFVT (Finance Code 001). CNPq provided financial support to AAG's lab. CNPq provided a research grant to AAG (\#305261/2010-0). Collection permits were conceded by SISBio/ICMBio (\#30059; \#33507-1).

\section{References}

Angulo, A. and S. Reichle. 2008. Acoustic signals, species diagnosis, and species concepts: the case of a new cryptic species of Leptodactylus (Amphibia, Anura, Leptodactylidae) from the Chapare region, Bolivia. Zoological Journal of the Linnean Society 152: 59-77.

Blair, F. W. 1958. Mating call in the speciation of anuran amphibians. American Naturalist 92: 27-51.

Blair, F. W. 1964. Isolating mechanisms and interspecies interactions in anuran amphibians. Quarterly Review of Biology 39: 334-344.

Boul, K. E., W. C. Funk, C. R. Darst, D. C. Cannatella, and M. J. Ryan. 2007. Sexual selection drives speciation in an Amazonian frog. Proceedings of the Royal Society $B$ 274: 399-406.

Carvalho, T. R., A. A. Giaretta, A. Angulo, C. F. B. Haddad, and P. L. V. Peloso. 2019. A new Amazonian species of Adenomera (Anura: Leptodactylidae) from the Brazilian state of Pará: a tody-tyrant voice in a frog. American Museum Novitates 3919: 1-21.

Castroviejo-Fisher, S., C. Vilà, J. Ayarzagüena, M. Blanc, and R. Ernst. 2011. Species diversity of Hyalinobatrachium glassfrogs (Amphibia: Centrolenidae) from the Guiana Shield, with the description of two new species. Zootaxa 3132: 1-55.

Center for Conservation Bioacoustics. 2014. Raven Pro: Interactive Sound Analysis Software. Version 1.5. URL: http://www.birds.cornell.edu/raven.

Cintra, C. E. D., H. L. R. Silva, and N. J. S. Junior. 2013. New state record of Vitreorana eurygnatha (Lutz 1925) (Anura: Centrolenidae) in Brazil. Herpetology Notes 6: $587-590$

Dautel, N., A. L. S. Maldonado, R. Abuza, H. Imba, K. Griffin, and J. M. Guayasmin. 2011. Advertisement and combat calls of the glass frog Centrolene lynchi (Anura: Centrolenidae), with notes on combat and reproductive behaviors. Phyllomedusa 10: 31-43.

Duellman, W. E. and R. A. Pyles. 1983. Acoustic resource partitioning in anuran communities. Copeia 1983: 639_ 649.

Escalona, M. D., P. I. Simões, A. Gonzales-Voyer, and S. Castroviejo-Fisher. 2019. Neotropical frogs and mating songs: the evolution of advertisement calls in glassfrogs. Journal of Evolutionary Biology 32: 163-176.

Guayasamin, J. M., S. Castroviejo-Fisher, L. Trueb, J. Ayarzagüena, M. Rada, and C. Vilà. 2009. Phylogenetic systematics of Glassfrogs (Amphibia: Centrolenidae) 
and their sister taxon Allophryne ruthveni. Zootaxa 2100: 1-97.

Haga, I. A., F. S. Andrade, N. P. Toscano, A. Kwet, and A. A. Giaretta. 2014. Advertisement call and habitat of Vitreorana uranoscopa (Anura: Centrolenidae) in Brazil. Salamandra 50: 236-240.

Heyer, W. R., A. S. Rand, C. A. G. Cruz, O. L. Peixoto, and C. E. Nelson. 1990. Frogs of Boracéia. Arquivos de Zoologia 31: 235-410.

Höbel, G. and H. C. Gerhardt. 2003. Reproductive character displacement in the acoustic communication system of Green Tree Frog (Hyla cinerea). Evolution 57: 894 904.

Hoskin, C. J., M. Higgie, K. R. McDonald, and C. Moritz. 2005. Reinforcement drives rapid allopatric speciation. Nature 437: 1353-1356.

Irwin, D. E., M. P. Thimgan, and J. H. Irwin. 2008. Call divergence is correlated with geographic and genetic distance in greenish warblers (Phylloscopus trochiloides): a strong role for stochasticity in signal evolution? Journal of Evolutionary Biology 21: 435-448.

Jansen, M., M. Plath, F. Bruquetti, and M. J. Ryan. 2016. Asymmetric frequency shift in advertisement calls of sympatric frogs. Amphibia-Reptilia 37: 1-16.

Köhler, J., M. Jansen, A. Rodríguez, P. J. R. Kok, L. F. Toledo, M. Emmrich, F. Glaw, C. F. B. Haddad, M-O. Rödel, and M. Vences. 2017. The use of bioacoustics in anuran taxonomy: theory, terminology, methods and recommendations for best practice. Zootaxa 4251: $1-124$

Ligges, U., S. Krey, O. Mersmann, and S. Schnackenberg. 2018. TuneR: Analysis of Music and Speech. URL: https://CRAN.R-project.org/package=tuneR.

Lisboa, B. S., W. F. S. S. Santos, S. T. Silva, M. C. Guarnieri, and T. Mott. 2019. A new state record of the glassfrog Vitreorana baliomma (Anura: Centrolenidae), with notes on its reproductive biology. Herpetology Notes 12: $957-$ 960.
Paz, A., Z. Spanos, J. L. Brown, M. Lyra, C. F. B. Haddad, M. T. Rodrigues, and A. Carnaval. 2018. Phylogeography of Atlantic Forest glassfrogs (Vitreorana): when geography, climate dynamics and rivers matter. Heredity 122: 545-557.

Pontes, R., U. Caramaschi, and J. P. Pombal Jr.. 2014 A remarkable new Glass Frog (Centrolenidae: Vitreorana) from the northeast Atlantic Forest, Brazil. Herpetologica 70: $298-308$.

R Development Core Team. 2015. R: A Language and Environment for Statistical Computing. Version 3.2.3. URL: http://www.R-project.org.

Santana, D. J., A. B. Barros, R. Pontes, and R. N. Feio. 2015. A new species of Glassfrog genus Vitreorana (Anura, Centrolenidae) from the Cerrado domain, southeastern Brazil. Herpetologica 71: 289-298.

Sueur, J., T. Aubin, and C. Simonis. 2008. Seewave, a free modular tool for sound analysis and synthesis. Bioacoustics 18: 213-226.

Velásquez, N. A., J. Marambio, E. Brunetti, M. A. Méndez, R. A. Vásquez, and M. Penna. 2013. Bioacoustic and genetic divergence in a frog with a wide geographical distribution. Zoological Journal of the Linnean Society 110: $142-155$.

Velásquez, N. A., F. N. Gómez-Moreno, E. Brunetti, and M. Penna. 2018. The acoustic adaptation hypothesis in a widely distributed South American frog: southernmost signals propagate better. Scientific Reports 8: 6990.

Wells, K. D. 2007. The Ecology and Behavior of Amphibians. Chicago and London. University of Chicago Press. 1148 pp.

Zaracho, V. H. 2014. Redescription of the advertisement call of Vitreorana uranoscopa (Müller, 1924) (Anura, Centrolenidae) from the Argentina Atlantic Forest, with notes on natural history. South American Journal of Herpetology 9: 1-7. 


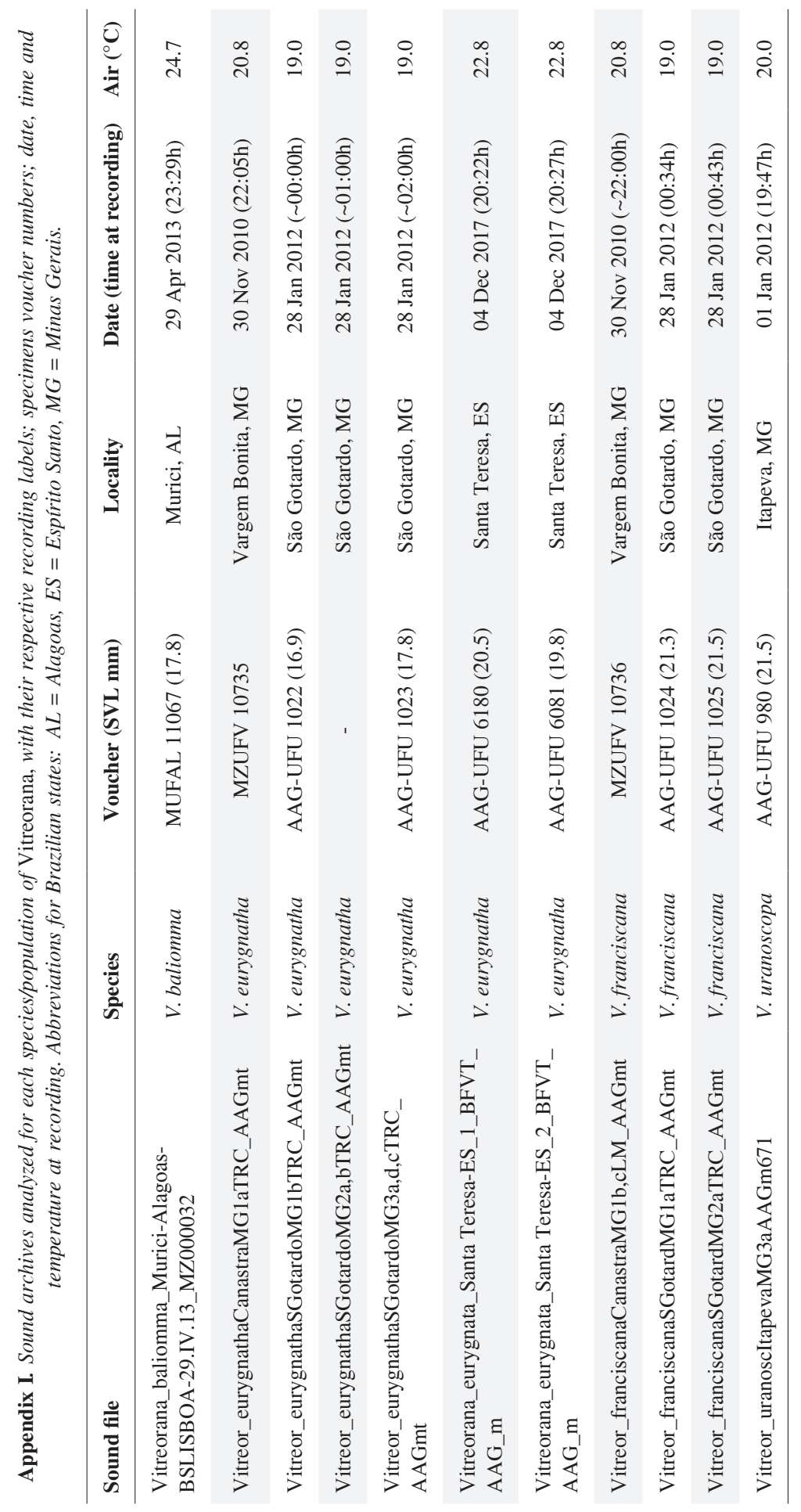

